\title{
Stories and Maps, Images and Archives: Multimethod Approach to the Political Ecology of Native Property Rights and Natural Resource Management in Sabah, Malaysia
}

\author{
Amity A. Doolittle
}

Received: 11 September 2006/Accepted: 27 April 2008

(C) Springer Science+Business Media, LLC 2008

\begin{abstract}
The study of human-environmental relations is complex and by nature draws on theories and practices from multiple disciplines. There is no single research strategy or universal set of methods to which researchers must adhere. Particularly for scholars interested in a political ecology approach to understanding human-environmental relationships, very little has been written examining the details of "how to" design a project, develop appropriate methods, produce data, and, finally, integrate multiple forms of data into an analysis. A great deal of attention has been paid, appropriately, to the theoretical foundations of political ecology, and numerous scholarly articles and books have been published recently. But beyond Andrew Vayda's "progressive contextualization" and Piers Blaikie and Harold Brookfield's "chains of explanation," remarkably little is written that provides a research model to follow, modify, and expand. Perhaps one of the reasons for this gap in scholarship is that, as expected in interdisciplinary research, researchers use a variety of methods that are suitable (and perhaps unique) to the questions they are asking. To start a conversation on the methods available for researchers interested in adopting a political ecology perspective to human-environmental interactions, I use my own research project as a case study. This research is by no means flawless or inclusive of all possible methods, but by using the details of this particular research process as a case study I hope to provide insights into field research that will be valuable for future scholarship.
\end{abstract}

\footnotetext{
A. A. Doolittle ( $\square)$

Yale School of Forestry and Environmental Studies, 205

Prospect Street, New Haven, CT 06511, USA

e-mail: amity.doolittle@yale.edu
}

Keywords Qualitative research · Multimethod approach · Political ecology · Grounded theory · Inductive reasoning · Native customary land tenure

Interdisciplinary research will represent one of the frontiers of scientific inquiry in the 21 st century as scientists elucidate the dynamics of complex and interdependent social and natural systems.

$$
\text { -Ann Kinzig }
$$

The study of human-environmental relations is complex and by nature draws on theories and practices from multiple disciplines. There is no single research strategy or universal set of methods to which researchers must adhere. As a result there is tremendous opportunity for creativity in defining a research project, and methods can be legitimately borrowed from many disciplines. This freedom comes with a cost. If there is no single standard, how do we know we are doing it "right"?

As a student interested in the field of political ecology in the early 1990s, I found that my tendency to value inductive reasoning, holistic thinking, case-oriented research, and qualitative methods did not fit neatly into the research models with which the majority of the university faculty were familiar. By far the dominant research paradigm, even at an interdisciplinary school of environmental studies, was based on deductive logic, reductionism, predefined analytical units, and variable-driven hypotheses.

In the ensuing decade and a half much has changed. First, most graduate schools in environmental studies now offer a variety of courses in research methods. Some schools offer survey courses that introduce a range of research methods used in the humanities, public policy, 
social sciences, and biological and ecological sciences. Other schools offer courses on quantitative methods and/or qualitative methods. A second important change is that the field of political ecology has grown and strengthened. Numerous books exploring different aspects of political ecology have emerged, each providing different and complementary perspectives (Bryant and Bailey 1997, Forsyth 2003, Neumann 2005, Paulson and Gezon 2005, Peet and Watts 1996, Robbins 2004, Stott and Sullivan 2000, Zimmerer and Bassett 2003). All of these books provide some insights into research methods, most notably the contributors to Susan Paulson and Lisa Gezon's book (2005), but more explicit focus on methods is still needed. Materials that provide greater transparency in research design, the practice of data collection, and the development of theory are lacking (cf. Demerath 2006). In general, little attention is paid to how research is carried out and how research materials are produced (Vershuren 2001).

The primary aim of this article, therefore, is to orient researchers to a single case study of a qualitative research project, informed by the field of political ecology. Given the interdisciplinary nature of political ecology, it stands to reason that some potential methods are left out in the case study presented here. No one project can be all-encompassing. In particular, the research project described below favors qualitative methods over quantitative ones, and does not include the use of the rich spatial data that are currently available through satellite imagery and geographic information systems (GIS). Therefore, the following case study is not meant to be a manual to follow but, rather, is a case study designed to start a conversation on the range of methods available to researchers interested in aspects of the human-environment relationship. This article does not describe a novel approach to research design and data collection for social science (see Babbie 2004, Bernand 2006, Booth, Colombo, and Williams 2003, Creswell 2003, Denzin and Lincoln 1998, Hesse-Biber and Leavy 2005, Lincoln and Denzin 1994, Russell and Harshbarger 2003, Stake 1995, Weiss 1994, Yin 2002) but, rather, aims to make explicit a process that is rarely written about (notable exceptions, using a political ecology perspective, are Rocheleau [1995] and Fortmann [1996]). As a case study, the research presented here can be used as a starting point to design other research projects.

\section{A Holistic Research Strategy}

The approach used in this research is holistic. During the research process complexes of information and meaning were explored, with attention to finding patterns, anomalies, processes, and types. The vantage point from which this research was designed presumes that knowledge, data, and facts cannot be separated from either the researcher or the context in which data are collected. The corollary to this statement is the belief that empirical research in the social sciences can be highly problematic (Alvesson and Skoldberg 2004, p. 2). Therefore this research is built primarily on qualitative data. This is not to suggest that there is no use for quantitative data. There are times in most research projects when empirical data are necessary, not as objective measures or "reality," but as another set of data, another viewpoint that needs to be incorporated into the larger interpretation of the social world.

An important characteristic of holistic research is the use of qualitative comparison (Ragin 1989, 1994) in order to build theory. How does this work? It is often postulated that qualitative research relies on inductive reasoning. A pure inductive approach suggests that the researcher would enter the field with no preconceived theoretical notions. Understandings or theories should be generated from the data themselves, from the ground up. This approach is often set in opposition to deductive reasoning, in which a theory is first adopted and a hypothesis is generated to verify or falsify the existing theory. But inductive and deductive models of research cannot be so easily disentangled. Sociologist Gary Fine (2004, p. 111, original emphasis) summarizes the ways in which we use both deductive and inductive reasoning in everyday life:

As 'natural' persons we are continually learning from our situational exposure and from what we have been assured by others. We are inductive theorists. But we then use this learning to assume and to create expectations about how the world operates. We are deductive theorists.

This description of logical reasoning captures the intent of grounded theory (Glaser and Strauss 1967). Grounded theory is a research approach designed explicitly to link inductive and deductive thinking as part of an iterative research process. The process begins with developing research questions, based on existing knowledge and theory. As data are collected and analyzed, temporary or working theories are developed using inductive logic. This "emergent theory" is then tested with new data collection, using deductive logic. The theory is adjusted to account for new data (if needed) and then the cycle begins again (Glaser and Strauss 1967, Creswell 2003, Vershuren 2001). This process is also referred to as a reflexive approach to research - the researchers should continuously reflect on their project, on the data they have collected, and the data needed to provide a coherent analysis that grounds theoretical arguments in the data (Alvesson and Skolberg 2004, Creswell 2003).

The following section begins with a brief summary of the research project to provide a context for the remaining 
sections. For ease in understanding the case study, the project is not presented in an entirely linear (or chronological) fashion. By presenting a research summary first, the article enters the research process at the end, but from that point forward the article backtracks to the beginning of the research process. The second section discusses how the research questions related to this particular project were developed based on gaps and controversies in the literature.

From the generation of research questions and objectives to guide inquiry, the article moves to the specific types of data needed to answer the questions and the methods used to acquire the data. In the third section, examples of different methods and the types of data that each method produces are highlighted through two case studies. This section illustrates the various forms of data that can be collected in the field and then demonstrates how these types of data can be woven together to achieve triangulation and validity in a qualitative research project.

\section{History, Ethnography, and the Landscape}

\section{Research Summary and Framework}

The overall goal of the project was to illuminate contemporary land-use issues in Sabah, Malaysia, by examining native customary rights of access to land and resources. The research sought to understand the ways in which colonial and postcolonial state rulers interacted with native people over land rights, from 1881 to 1996 . Drawing on theory and methods from anthropology, political science, environmental history, and political ecology, the project explored how control over resources has been defined, negotiated, and contested by colonial state agents, the postcolonial Malaysian state, and natural resource-dependent communities for over a century. The aim of the project is to understand the rich and complex history of native property rights and land disputes, and the ways in which the state has constrained and expanded native rights of access to resources.

Following one of the defining characteristics of political ecology research, scale is an integral component of this project. In a multiscalar approach to human-environmental relationships, the study moves beyond a singular geographic location, a snapshot of time, and one level of social organization. By exploring a diversity of spatial, temporal, and organizational scales, and the interactions between these scales, research becomes richer, more nuanced, and ultimately more meaningful for policy. In line with a multiscalar approach, data for this project were collected from native people at the household and village level, midlevel district officers in Sabah, heads of key administrative departments, and upper-level state officers representing the Malaysian state. Historical data were gathered from colonial archives in England; contemporary documents and newspaper reports were collected to compare the policies and practices of the colonial and postcolonial state. Finally, in addition to the plurality of temporal and organizational perspectives, this research compared present-day land and resource issues in two villages of the same ethnic group, in the same region, thus achieving variations along a geographic or spatial scale.

With this context in place, the following section looks at how research questions were developed and how research objectives can be used to create a guide to data collection.

\section{The Question of Research Questions}

During the literature review, material should be read critically, with an eye toward finding puzzles, gaps, and contradictions. Generally, these puzzles fall under four broad categories: historical controversies, theoretical debates, accepted wisdom, and contemporary policy debates. In the following paragraphs the details (without providing a complete literature review) of the four puzzles that helped to shape this research are outlined.

\section{A Historical Controversy}

Throughout the English colonies in Africa and Asia British colonialists obliterated native customary law by imposing English statutory law, requiring all natives to settle (prove) land claims and become tax-paying citizens through documented land ownership (Guha 1963, Moore 1986, Peters 1994). The land titling process resulted in the erasure of local property relations and resource management regimes. New property relations were created, and at times colonialists supported the formation of a new ruling class who became complicit in the colonial project (Berry 1993, Guha and Ranajit 1963, Zerner 1994). Yet, in the process of wide-scale land settlement and privatization in British North Borneo, the colonial government allowed the villagers in Govuton (a pseudonym) to collectively declare 3100 ha as a "Native Reserve" to be governed by native customary law. What were the conditions under which the colonial authorities, who were largely driven by the desire to privatize land rights, would allow for over 3000 ha to be set aside as communal land? The discovery of this break from normal colonial policy emerged only after months of pouring over colonial archival records in Kew, England. Relying on inductive reasoning, the initial phases of the archival inquiry were not guided by a specific, focused research question, as much as by an exploratory approach to research. The aim was to see what material could be uncovered relating to native customary law and land rights. In other words, the data in the archives were integral in the 
initial development of the research question. These data facilitated the selection of a study site, the village of Govuton, where the Native Reserve was still intact in the present day.

\section{Theoretical Debates on State Power and Local Agency}

There are various perspectives on the relationship between state power and local agency. Three perspectives are briefly outlined below in highly simplified versions of this relationship, for the purpose of illustration. First, scholars have argued that political and economic processes of colonialism and capitalism are powerful juggernauts that exploit poorer nations on the periphery in order to sustain the wealth and economic growth of the colonial empire (Frank 1967, Wallerstein 1974). In this line of thinking, marginalized countries and people are caught in a system of dependency on the nations that have the political power and technology to control the global capitalist economy. Yet, in contrast to this view, other scholars have shown how local people are able to avoid total domination through various forms resistance; colonial rule was not as hegemonic as once supposed (Comaroff 1989, Scott 1985, Stoler 1985). Still others argue that local groups can successfully alter and modify the processes of colonial dominance and capitalism to their own advantage (Agrawal and Sivaramakrishnan 2000, Merry 1988, 1991, Midgal and others 1994, Sivaramakrishnan and Agrawal 2003). These varying views on the nature of state power and civil society helped generate the following question: Which, if any, of these theoretical perspectives on the flows of power apply to the relationship between British colonial rulers of North Borneo and native people? Were native people in Sabah passive agents, subject to domination, or did they rebel, forcing partial colonial retreat? Or did native people modify the impacts of state rule through negotiations and compromise with the state?

This set of broad theoretical questions on state-society relations was further specified by looking at the changing nature of property relations under both colonial and postcolonial states. Attention to property relations opened up additional theoretical debates about the supposedly evolutionary nature of property regimes from open access to common property to private property in response to emerging markets and increasing political organization (Locke 1963 [1690], Demetz 1967). In contrast to this evolutionary view of property rights, many other scholars have argued that ownership of land and resources is governed by complex social relationships between people that may contradict the logic of economic theory, drawing on a moral economy based in specific cultural values (Berry 1993, MacPhearson 1978, Moore 1986, Ostrom 1990, Peters 1994, Rose 1994). Drawing on the debates in the literature on property relations, this research explored whether such a deterministic and evolutionary change in property regimes was true for native people in North Borneo as the region went through several changes in statesociety relationships. And additionally, the research focused on discovering the social nature of property relations and sought to recognize how social relationships might change customary rights to land and resources as society adapts to varying forms of state rule.

\section{Accepted Wisdom}

According to accepted wisdom, native shifting cultivators are responsible for more forest destruction than any other user group (Bryant 1997, Chandran 1998, Pouchepadaas 1995). The work of many ecological anthropologists has tried to dispel this thinking (cf. Conklin 1957, Dove 1983, Fox and others 2000), yet the myth still holds power over policymakers. More specific to this study, the British colonial archives were filled with detailed language outlining the scientific and economic superiority of colonial political, legal, economic, and agricultural systems. And in contrast, native agriculturalists were portrayed as ignorant and lazy, and their cultivation systems were seen as wasteful and destructive of natural resources. In contemporary Sabah this discourse continues-natives are seen as ignorant, backward, and responsible for environmental degradation. The sheer power and dominance of the language of superiority found in the colonial archives, in relation to the reality of environmental change, led me to question how colonial knowledge regarding native people and natural resources became so ingrained and naturalized that it still holds power in contemporary Sabah? Why, after so many years of scholarship, are marginalized people still blamed for resource degradation? The goal of this research was to trace the roots of this discourse, and the reasons for its continuation, and to determine its effects on current land use policies and practices in Sabah.

\section{Contemporary Policy Debates}

Is the protectionist model or community-based model of conservation the most effective means to conserving biodiversity? For decades (in some places, well over a century), conservation has been based on the model of state-driven, top-down protection of valuable landscapes, often referred to as either protectionist (cf. Nash 2001, Redford and others 2006, Terborgh 1999) or fortress (Brockington 2002) conservation. In this model the conservation agenda is set by the state, while the resourcedependent communities surrounding protected areas generally bear the weight of either loss of access to their means of survival, significant fines attached to activities that once 
were the basis of their livelihoods, or even displacement from ancestral lands (Neumann 1998, Peluso 1993). Hunters become poachers, customary use of resources on land that was once community-held is considered encroaching on park boundaries, farmers become squatters, and daily use of nontimber forest products in protected areas is considered illegal (Guha 1989, Neumann 1998, Peluso 1993).

Much (but not all) of the international conservation community has slowly come to agree that the protectionist model is not socially just, and may not even be the most effective way to protect biodiversity (Brockington 2002, Brechin and others 2003, Dove and others 2005, Guha 1997, 1998). Over the past two to three decades there has been a growing consensus that the active participation of communities is a necessary ingredient to ensure successful conservation (Agrawal 2005, Agrawal and Gibson 2001, Leach and Fairhead 2000, Leach and others 1999, Murphree 2005). This has led to the development of community-based conservation models, in which community members are seen as partners in developing conservation strategies, monitoring violations, and receiving economic compensation for loss of access to land, usually from the tourism-generated revenue (Wells and Brandon 1992).

However, after over a decade of mediocre success with community-based conservation, this model too has now come under scrutiny. Many argue that it often fails to protect biodiversity, the bulk of the profits go to the elite running the tourism industry and not the local people, and community members feel little empowerment or autonomy in decision-making (Barrett and others 2001, Brockington 2002). This debate leads to the question: Are natural resources in Sabah best protected by a protectionist model or a community-based model? Since protectionist conservation was the dominant model in the study region, one focus of this research was to determine the successes and failures of this conservation policy. Additionally, the research explored community dynamics to see if possibilities existed for conservation and the sustainable use of resources using a community-based model.

This combination of these four different puzzles and controversies in the literature led me to ask the overarching question: How did the British colonial regimes of power and governance over natural resources and native people in Sabah, Malaysia, influence the shape of the contemporary landscape, land rights, land use decisions, and natural resource-based conflicts at the local level?

\section{Site Selection}

In the case of this project, selection of the primary research site was based on archival data. While reviewing archival materials, one village stood out as unique in terms of its history of property relations. This was the village that I call Govuton, where the village leaders had been able to negotiate with the colonial state and received recognition of their native customary land rights in the form of communal village title to their traditional lands. As mentioned above this was an important achievement at a time when the colonial rulers were intent on introducing individual property rights. Reading through the personal papers of a district officer who explored North Borneo during 18971898, I found a sketch and a written description of Govuton and the surrounding landscape. The following excerpt from W. R. Dunlop's diary was written on 17 February 1897:

[The village] is situated on the slopes of hills about 1500-2000 feet high with steep hills cut into ridges by numerous streams coming down, there is very little jungle, the slopes mostly being covered with turf kept short by numerous kerbau [water buffalo], cattle, goats, and pigs. The houses large and small numbering at least 200 face each other on the slopes and are surrounded by pinang [betel nut], coconuts, and other trees and altogether the place has the appearance of an old prosperous homestead. The ground has every appearance of being very rich.

This diary entry showed that at the landscape level, there were few major changes in Govuton over the past century. The description from 1897 largely held true a century later. The history of this relatively stable village that had managed to negotiate with colonial officers for community control of their land rights was intriguing. Did this unique history have positive or negative impacts on ownership and access to land and resources in the present day? Comparing the present-day property rights and natural resource management practices between Govuton and a neighboring village of Tempulong (with a very different history of interactions with the state over native customary law) provided a fascinating opportunity for a comparison focusing on the impact of colonial rule on native land rights.

One other factor was important in site selection for this project. Given my interest in the intersection of conservation and local livelihoods, it was important that the study sites were located on the border of a major conservation area. Govuton and Tempulong also fit this requirement.

\section{Integration of Multiple Forms of Data}

One of the central challenges to interdisciplinary research lies in the integration or weaving together of various forms of data. Two case studies are presented in the following section. Each of these vignettes draws together several 
different types of data, demonstrating some of the ways that varying forms of data can be integrated in an analysis.

The first case study focuses on the ways in which multiple forms of archival data from various colonial sources can be read together in an effort to understand colonial perspectives of North Borneo, native people, and the colonial mission. The second case study uses multiple types of data from village-level research to illustrate the social relationships that shape native land tenure and natural resource use.

Case 1: Colonial Plantation Agriculture Versus Native Shifting Cultivation

Below are four pieces of archival data. They are excerpts from (1) an 1890 report by the governor of North Borneo, William Treacher, (2) a piece of colonial legal legislation called the "Ladang Ordinance" from 1913, (3) a report on forestry and shifting cultivation from 1914, and (4) a diary entry by a European plantation owner from 1922. While these four excerpts are not sufficient for a thorough analysis on their own, combined with hundreds of other documents, they provide insights into the ways in which colonial leaders and plantation owners viewed natives, their customary laws, and their land use systems. These views can be seen as part of the system of knowledge that the colonial elite created in order justify their extraction of valuable natural resources at the expense of native peoples.

\section{Governor Treacher's Report, 1890}

In his description of Labuan, an island off the shores of Brunei, Governor Treacher (1890, p. 43) reported that valuable timber trees had been destroyed

chiefly by the destructive mode of cultivation practiced by the Kadyans and other squatters from Borneo, who were allowed to destroy the forest for a crop or two of rice, the soil...not being rich enough to carry more than one or two such harvests under such primitive methods of agriculture as only known to natives.

\section{The 1913 Ladang Ordinance}

In 1913 the Company introduced legislation known as the Ladang [dry field agriculture] Ordinance. The primary aim of the ordinance "was to restrict the destruction of forests by felling them for temporary cultivation only" (Government of North Borneo 1914). In the ordinance, ladang cultivation was defined as "the successive occupation of different pieces of land in such a manner that any one piece is not cultivated for more than two consecutive years and is then abandoned." Realizing that this definition of shifting cultivation would also include plantation tobacco, the ordinance specifically provides "that the use of land for the cultivation of 'Wrapper Leaf' tobacco shall not be deemed to be 'ladang cultivation" (Government of North Borneo 1937 , p. 74). Thus, the ordinance was aimed at controlling only native forms of shifting cultivation, subsistence-oriented, dry rice swiddens, not European shifting-cultivation, profit-oriented tobacco plantations.

Colonial Report on Forestry and Shifting Cultivation, 1914

The practice of shifting cultivation ... is the origin of the greatest annual loss to the timber supply. It is the greatest evil with which a Forest Officer has to contend, and the less civilized and developed the country is, the harder it becomes to keep the annual destruction within bounds.... The property is ruined by shifting cultivation, inasmuch as the land is almost invariably subjected to fire which extends beyond the area designed for cultivation, and effectively kills all seeds and seedlings which may be in its range. When cultivation is abandoned 'lalang' or swordgrass appears and the land is practically valueless. (Pearson 1914)

Journal Excerpt from Owen Rutter, an English Plantation Owner, 1922

In North Borneo new cessions are either under virgin jungle or secondary jungle and the preliminary work of clearing the land is usually given out to the native contractors who thoroughly understand it. There is only one sight more inspiring than a great jungle giant crashing to the ground, and that is a block of jungle burning when it has been felled and stacked. The day for the fire is a most momentous question, for a good clean burn will save the planter thousands and a bad one will leave the estate strewn with useless timber. A burn on a fine day is well worth waiting for. The coolies are in the highest spirits, whooping with glee as they see the long tongues of fire leaping up, crimson as tulips, soon the whole hill-side is ablaze, rising and falling, a sea of flame. The smoke curling heaven-high, veils the rising sun and makes it glow a rich dull red as in London on a foggy November morning... When it is over ... [t]he planter surveys the scene and feels content, for all has gone according to plan, he has tamed the untamable. (Rutter 1922, p. 246)

\section{Brief Analysis}

Throughout Company rule in North Borneo, administrators continuously expressed their disapproval of the wasteful 
native practice of shifting cultivation while valorizing European plantation cultivation. However, the notion that native shifting cultivation was destroying the territory's forests was in fact not documented in any scientific or systematic fashion by the Company. But empirical evidence was not necessary since colonial ideology was so firmly entrenched that few colonialists doubted that the plantation system was inherently more scientific than native cultivation practices, that economic rationality was a far superior logic than other forms of production, and that there was an inherent moral weakness and ecological ignorance that kept indigenous people from economic (and moral) advancement.

The quote from Owen Rutter reflects the strength of this belief; it demonstrates that there was in fact very little difference between native agricultural practices and colonial practices in terms of the clearing and burning of the forest. In fact tobacco plantations, the main export crop of the North Borneo Charted Company, were managed on a rotational, or shifting, cycle in which a plot of land was used for one harvest and then abandoned, precisely like native practices (Doolittle 2005). But Rutter is able to ignore the striking similarities since in his mind's eye he sees a flourishing, ordered plantation on his land, not subsistence, "haphazard" agriculture. The concern that native shifting cultivators were wasting valuable forest resources disguised the primary intent of the Company-to generate revenue for its shareholders in England. Tobacco plantations provide an export crop that was sold on the international market. And the plantations owners contributed to the state coffers through purchase of "crown lands" and payment of land taxes and export fees. In brief, it was not the environmental impacts of shifting cultivation that bothered the colonial rulers, but rather it was the subsistence or noneconomic nature of their native agricultural systems. Furthermore, native agriculturalists got in the way with plantation development and needed to be restricted. Using the rhetoric of scientific versus traditional, efficient versus wasteful, and modern versus primitive, the colonial rulers valorized plantation agriculture and denigrated native agriculture. In doing so they legitimized the colonial mission to "civilize" the colonies.

\section{Case 2: Social Nature of Property Relations}

In the following set of data the focus of inquiry moves away from the historical context to the present day. The data presented below highlights the social nature of local property relations from a variety of perspectives. These data are: (1) an anonymous letter of grievance on file in the district office, (2) a traditional story told during an in-depth interview with an elder man, (3) an explanation of property relations from an in-depth interview with a woman, (4) data from participant observation and interviews, and (5) results of a household economic survey, (6) a map, the product of sketch maps, interviews, observation, and regional maps. Each of these sources of data viewed alone is interesting, but not sufficient to provide a clear understanding of property relations. But as dozens of similar stories and interviews reveal similar trends, a clearer understanding of the factors affecting local property relations begins to emerge. Given the complexity of these social data, each entry presented below is coupled with some context and explanation.

\section{Letter of Grievance on File in Regional District Offices, June 1993}

The excerpt below is my translation of an anonymous letter dated June 1993 that was sent to the district officer and held on file in the district office. The author of the letter is complaining about one individual in the village of Govuton who has been able to accumulate, and in effect has "privatized," land in the Native Reserve. According to customary law, villagers should have equal usufruct rights to land; no one person has the authority to claim permanent ownership of land within the Native Reserve. But the individual referred to in the letter, Intang (a pseudonym), had used various coercive techniques to exclude other villagers from large sections of village land. These techniques included planting permanent crops on the land, fencing it off, and investing in irrigation pipes. Intang also was a money lender in the village, and when people did not pay him in a timely manner he would seize their land or portions of their harvest. These actions effectively removed village land from the agricultural-fallow cycle, which was one mechanism by which village land had historically been reallocated within the village, by the headman. Intang had used his wealth and power to accumulate village land in a manner that violated local norms associated with a moral economy (see Scott 1976, Thompson 1971) that supported shared access to community resources.

In other words he was privatizing land that was considered shared community land. The letter reads:

The people of [Govuton] say with sadness and ask for sympathy from the District Officer since we have suffered abuse from Intang. He thinks he is rich and therefore can do whatever he wants. Those who have suffered under Intang need to work together to solve the problem that they are facing. We believe that if this issue is not defended by us our village will become the property of one person. Already several houses have been destroyed by him so he can make a garden... Nearly everyone, from the young children to old people are involved in Intang's work as he 
buys our land either through sweet talk or force...We are less loved than dogs by Intang who extinguishes us as he wishes.

\section{Oral History: In-Depth Interview with an Elderly Man}

The following story about the formation of village boundaries in the village of Tempulong (a pseudonym for the second research site) also highlights the moral economy of community access to forest resources and the value of exchange and reciprocity in forming acceptable, local norms of resource use.

Many years ago the people in Tempulong shared a hunting area with the neighboring village of Bongkod. It was the custom of the two villages to share a campsite in the forest. When people from Tempulong were ready to return to their homes after hunting they would leave a supply of meat, vegetables, and rice for the next hunting group from Bongkod. People from Bongkod would do the same for Tempulong hunters. One day a hunting group from Tempulong stopped at the campsite. The storage bin was filled with deer meat, monkey meat, and plenty of vegetables and rice. As a trick or ruse, when the people from Tempulong left, they filled the bin not with food, but with feces. When the Bongkod hunters later found the bin filled with feces they were furious. They put a curse on the village of Tempulong. They said that the boundary between the two villages was fixed, near the river called Naluwad, and that they would no longer share the hunting area. People from Tempulong could never cross over into Bongkod land. If they did, great misfortune would fall on them. The curse also said that Tempulong villagers would never be prosperous and that no important headman would live to an old age.

This story must be interpreted in the context of village boundaries, shared natural resources, and resource management. The theme of a moral economy of shared access to resources and the importance of reciprocity in forming social bonds is reiterated throughout. A shared hunting ground between two villages suggests that cultural norms associate the absence of boundaries with culturally appropriate resource management strategies; valuable social bonds are forged through shared access to forest resources. The story suggests that physical boundaries to resources would also result in social boundaries between villages, which would undermine the traditional economic system of exchange and reciprocity that is found in many societies in Southeast Asia. Shared access to natural resources is symbolized not only by leaving a portion of the hunt, but also by leaving cultivated foods, which represent sharing aspects of village life. Such food-oriented hospitality is embedded in local notions of exchange and generosity and demonstrates symmetrical social relations and kinship ties (cf. Dove 1998, Evans 1922, Tsing 1993). In contemporary village life in Tempulong, whenever a hunter kills an animal, a portion of it, no matter how small, is shared with all extended family members. This practice is culturally elaborated as sharing a person's good fortune, and such generosity will be repaid when family members who have benefited from one person's good fortune in the past return the favor. In other interviews I was warned that a hunter who does not share his bounty will fall victim to a hunting accident. As in the story, when resources are not shared, misfortune is forecast.

By leaving feces instead of food in the cache, the villagers from Tempulong violated cultural norms of reciprocity; they acted in a greedy manner, taking resources but giving only an insult in return. It is implied that the failure to share the bounty of natural resources violates indigenous norms for redistribution and reciprocity and, therefore, bears a cost. At the end of the story, the punishment for Tempulong's greedy behavior is dissolution of the shared hunting ground. The boundaries cut off both access to natural resources and social relations between the two villages. The story suggests that without these social bonds of reciprocity, Tempulong and its residents would be isolated and village leadership would be weak.

\section{Oral History: In-Depth Interview with a Woman}

The following is from an interview with a woman regarding the differences in ownership between wild and cultivated resources on personal property. I had asked her to clarify the meaning of kepunya'an hutan [property of the forest], a local term I had heard repeatedly in reference to ownership of forest resources. In the interview below, the woman was explaining how a wild fruit tree can never be owned by one person, even if the person owns the sole rights to the land on which the tree grows.

Even if a wild durian tree is on your own land, you must guard it when the fruit begins to ripen. If you are not there, someone else can take the fruit. You must even sleep in a sulap [temporary garden shelter] under the tree. In one day 50-200 fruits can fall. Everyone who sits under the tree can have a share of the harvest.

This interview confirmed my understanding about the blending of two legal traditions in terms of land and resource ownership. According to local customary law all community members share access to the wild natural resources, regardless of who owns the land. There is a 
mixing of this customary law with statutory law, since the tradition of communal rights to wild resources holds true, even on land that individuals have been able to get private title to under the legal system introduced during colonialism.

\section{Data from Participant Observation, Surveys, and Interviews}

In early 1995 Sabah Parks began an initiative to protect the rare and endemic rafflesia plants (Rafflesia spp.) that are found in and around the park. As the largest (and smelliest) flower in the world, the rafflesia is a natural tourist attraction (Nais 1996). Researchers within the Sabah Parks Department established a "hotline" where tourists could call to find the location of blooming rafflesia plants. Local villagers were invited to participate in the Rafflesia Conservation Scheme by protecting rafflesia on their private property. Land owners were encouraged to charge an entrance fee for tourists to view the gigantic flowers. According to Sabah Parks, this community-based conservation scheme has the potential to be successful because it puts locals in charge of tending the blooms and safeguarding them from being cleared for gardening (Nais 1996).

The conservation plan, however, had unexpected negative consequences in Tempulong. One farmer found a rafflesia on his property. He set up a small booth on the roadside and charged tourists \$5 Malay ringitt (approximately U.S. \$2) to take pictures of the blooming flower. Many people in Tempulong were angry with him. According to the cultural norms of community access to forest resources, it was inappropriate for one individual to profit from the wild rafflesia flower. Wild plants are seen as kepunya'an hutan [property of the forest] and, as such, are considered to be community property, not private property. Personal gain from a forest resource violated community norms of exchange and reciprocity.

In the middle of the night the plant was destroyed, presumably by another villager. Villagers explained that an individual should not be allowed to profit by excluding others from community resources. In brief, the conservation scheme breeched the community's customary property relations, and therefore its effectiveness was compromised. The incident with the rafflesia plant also shows that villagers have conflicting views as to whether customary practices or statutory law should prevail in daily practice. The struggle over property rights parallels the variations between individuals who wish to remain on the margins of Sabah's growing economy and those who are looking for opportunities to enter the market economy. This case also shows that state-led commercialization of resources can lead to unpredictable disputes over natural resource use.

\section{Data from Surveys and Household Economic Journals}

In order to get a better sense of household reliance on forest resources, garden resources, and external income, a sample of households took part in daily household journals. In these journals one individual in the household (usually a literate, school-aged child) recorded, on a daily basis, all the garden and forest products used in the household and sold in the market, as well as external sources of income. The journals, which were recorded daily over 3 months, provided a different picture of dependency on forest and garden resources in the context of household economics. With more time and resources, it would have been valuable to collect a larger sample size than what is represented here. One constraint of the method is that it was dependent on many factors, e.g., a school-aged child who had the time and desire to record the necessary data, and a willingness on the part of all members of the household to communicate their information to the school children who were maintaining the journals. In order to get a sense of the accurateness of the journals, I visited each house in the group once a week to make sure that we understood each other and that the project was on course.

The households that took part in this participatory method were purposively selected (opposed to randomly selected) to represent the largest spectrum of socioeconomic groups in the village. Families that relied only on forest and garden products for subsistence purposes were compared with more affluent families that might have a male member earning a wage in addition to forest and garden products. Combining data from the household demographic and economic surveys with the data from the household journals revealed some interesting trends, which were confirmed through interviews (see Table 1). One noteworthy finding was the fact that there does not appear to be any direct relationship between wealth and dependency on forest resources. For instance, referring to Table 1, Lumbow's wage is similar to those of Selimboi, Gitom, and Lehimboi, yet his family relied on forest resources much less then the other families do. In a 3-month period, Lumbow's household only rarely spent time collecting forest resources. In contrast, groups of women from Selimboi, Gitom, and Lehimboi's households spent roughly a third of their working time collecting forest resources. Through interviews and participant observation (done while joining women on forest collection trips), it was determined that cultural values may be as important as subsistence needs in determining the amount of forest products a household uses. One woman told me, "Sometimes you just prefer the taste of lemiding [forest ferns] instead of eggplant." And during special festival times, the older villagers enjoy roasted songbirds as an accompaniment to their tapai [rice wine] drinking. For other villagers, such as Gamid, whose average 
Table 1 Household income and dependence on garden and forest resources in Govuton

\begin{tabular}{|c|c|c|c|c|c|}
\hline $\begin{array}{l}\text { Head of } \\
\text { household }\end{array}$ & $\begin{array}{l}\text { Household } \\
\text { size }\end{array}$ & $\begin{array}{l}\text { Average } \\
\text { monthly } \\
\text { income }\end{array}$ & $\begin{array}{l}\text { Percentage of income } \\
\text { from sale of nontimber } \\
\text { forest products \& } \\
\text { produce from garden }\end{array}$ & $\begin{array}{l}\text { Percentage of days } \\
\text { spent gathering } \\
\text { nontimber forest } \\
\text { products over 3-months } \\
\text { period }(\%)\end{array}$ & Types of resources collected \\
\hline Lehimboi & 9 & $\$ 1392$ & None & 35 & $\begin{array}{l}\text { Firewood, fish, squirrels, wild fruit, } \\
\text { wild vegetables, fodder for pigs }\end{array}$ \\
\hline Gitom & 14 & $\$ 1164^{\mathrm{a}}$ & $\begin{array}{l}\text { Garden: } 14 \% \\
\text { Forest: none }\end{array}$ & 34 & $\begin{array}{l}\text { Firewood, fish, frogs, monkeys, birds, } \\
\text { snake, armadillo, wild fruit, } \\
\text { wild vegetables, fodder for pigs }\end{array}$ \\
\hline Lumbow & 18 & $\$ 1078^{\mathrm{a}}$ & $\begin{array}{l}\text { Garden: } 75 \% \\
\text { Forest: none }\end{array}$ & 4 & Fish, wild vegetables \\
\hline Selimboi & 15 & $\$ 1062^{\mathrm{a}}$ & $\begin{array}{l}\text { Garden: } 6 \% \\
\text { Forest: none }\end{array}$ & 30 & $\begin{array}{l}\text { Firewood, fish, wild fruit, wild } \\
\text { vegetables, fodder for pigs }\end{array}$ \\
\hline Siking & 4 & $\$ 1025^{\mathrm{a}}$ & $\begin{array}{l}\text { Garden: } 30 \% \\
\text { Forest: none }\end{array}$ & 10 & Firewood, fish, wild vegetables \\
\hline Masin & 10 & $\$ 878^{\mathrm{a}}$ & $\begin{array}{l}\text { Garden: } 6 \% \\
\text { Forest: none }\end{array}$ & 41 & $\begin{array}{l}\text { Firewood, fish, wild fruit, wild } \\
\text { vegetables, fodder for pigs }\end{array}$ \\
\hline Gamid & 5 & $\$ 201^{\mathrm{a}}$ & $\begin{array}{l}\text { Garden: } 69 \% \\
\text { Forest: none }\end{array}$ & 89 & $\begin{array}{l}\text { Firewood, fish, wild fruit, wild } \\
\text { vegetables, fodder for pigs }\end{array}$ \\
\hline
\end{tabular}

a This figure combines both wage labor and income from the sale of garden products in markets

monthly income was only \$201 Malay ringgit (approximately U.S. \$80), the forest provides vital subsistence foods. These data point to the cultural and subsistence, the symbolic and material, importance of the forest.

\section{Data from Sketch Maps, Interviews, and Observation}

Sketch maps and transect walks are useful tools to engage a group of people in a discussion about village resources, boundaries, property relations, and land use regimes. Creating a map does not happen in one setting. Maps are generated many times and with different people. In these reiterative map-making sessions it is important to interview the authors of the maps in order to understand their explanation of village boundaries and variations in property regimes and land uses. The map presented in Fig. 1 was constructed from multiple sources: several sketch maps, interviews with people regarding their sketch maps, and surveyors' maps of the major boundaries in the district. The final product therefore is a composite map drawing together information from participatory mapping techniques, interviews, and state maps (see Fig. 1). One of the important aspects of this map is that it graphically illustrates surveyed land boundaries overlaid with the current practices of land use regimes. In particular, maps of this nature can highlight areas of conflict. Once made visible, the nature of multiple and overlapping domains of resource use can be identified, categorized as ideal, normative, or deviant behavior.

\section{Archival and Ethnographic Data in Conversation}

Reading these two vignettes together, we are able to bring historical events in context with present-day events. Even though the data presented above are brief, we can see many of the issues raised in theoretical review. For instance, returning to the theoretical debate on the nature of statesociety interactions, this research did highlight some of the fractures in the colonial project. As the formation of the Native Reserve in Govuton shows, there were some moments of powerful negotiations between the colonial state and the civil society. But a more dominant theme emerged from the archives. As a colonial government whose primary objective was generating revenue for British shareholders, the Company intended to settle all native land rights rapidly so that vacant lands suitable for plantation agriculture could be identified. But native land rights turned out to be exceptionally difficult to settle, and in the end, when the British turned North Borneo over to the Federation of Malaya in 1963, it left a tangled legacy of unresolved native property rights (Doolittle 2005).

Today conflicts rage over how native Sabahans can substantiate ancestral claims to land and over the thousands of land claims with counter claims on the same plot of land. In daily practice there is complex intertwining of customary law and shared access to community resources with statutory law and efforts to commercialize and privatize resources. Again, returning to the theoretical question on the supposedly evolutionary nature of property regimes, 
Fig. 1 Map of property relations in Tempulong. Horizontally hatched areas indicate land to which both the state and the village claim ownership

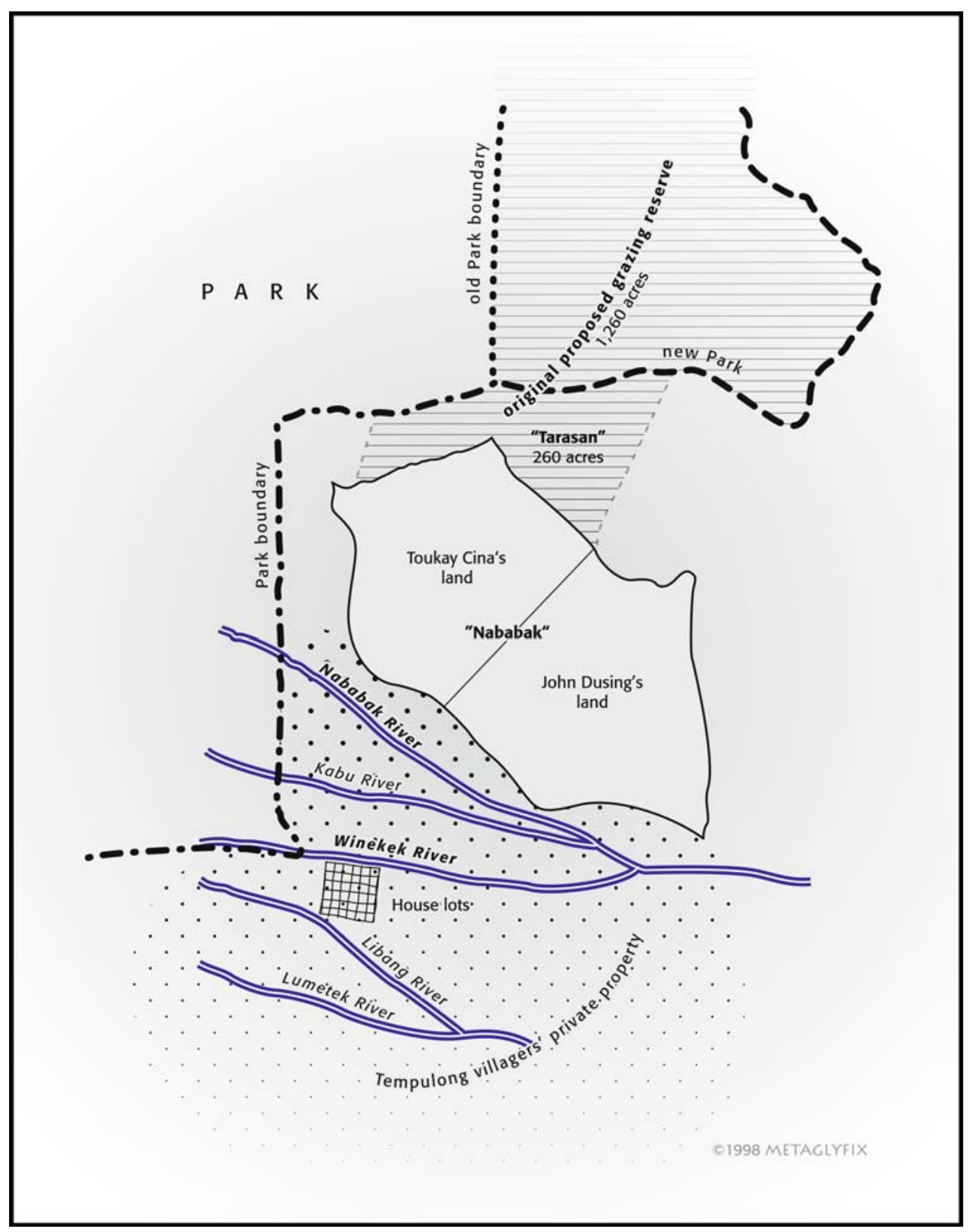

this research clearly demonstrates that there is no one pathway by which property rights change in response to emerging markets and centralized governance. As social relations change and as the value of resources changes, so do property rights change-but in unexpected ways.

One of the primary aims of this research was to bring a historical lens to understanding contemporary land and natural resource disputes in Sabah, and this line of inquiry turned out to be remarkably salient. The remaining two controversies in the literature that this research addressed did not come through as clearly in the limited data provided here (see Doolittle 2005). But these findings are, nonetheless, extremely powerful ones. By providing a historically rich perspective on property relations and community dynamics, this research has demonstrated that current state interventions into village life in Sabah continue to reproduce beliefs and practices that are deeply rooted in colonial ideologies that are over a century old. The colonial beliefs (highlighted above) are twofold. First, resource-dependent people are backward, lazy, and responsible for the past and current state of deforestation and resource degradation in Sabah. Second, state interventions are necessary to curtail subsistence-based agriculturalists' destructive and wasteful practices through the introduction of modern agriculture techniques. These ideologies served to legitimize colonial intervention in North Borneo.

These particular colonial ideologies and practices have endured into the present day since they are extremely 
effective techniques to ensure the entrenchment of Sabah's ruling class. Reinforcing the age-old rhetoric that native or indigenous people are the agents of land degradation, the postcolonial state is able to draw attention away from other more destructive uses of the landscape that benefit the political and economic elite. (such as copper mining, logging, and oil palm plantations). A close look at state-driven conservation projects and rural agricultural development initiatives in Sabah reveals that centralized practices of resource governance serve to support a long tradition of political cronyism at the expense of local livelihoods. Thus, efforts to develop community-based conservation efforts that would support sustainable livelihoods are a long way off. Not until the Malaysian government adopts an authentic democracy in which the interests of a wide section of society are accounted for will there be any hope for alternative conservation and development schemes that have outcomes other than supporting the political and economic future of the ruling elite.

\section{Conclusion}

Early writings on methods for political ecology (and similar approaches to understanding uman-environmental interactions) suggested that researchers should follow "chains of explanation" (Blaikie and Brookfield 1987) and use "progressive contextualization" (Vayda 1983). Blaikie and Brookfield (1987, p. 27) explain that the chain of explanation "starts with the land manager and their direct relations with the land... The next link concerns their relations with each other, other land users, and groups in the wider society who affect them in any way, which in turn determines land management. The state and world economy constitute the last links in the chain." Progressive contextualization refers to a path of inquiry where human-environmental interactions are explained by "placing them within increasingly wider or denser contexts" (Vayda 1983, p. 265) to determine the next step in inquiry while in the field. But what do these phrases really mean? How can we make them more meaningful so as to guide research? First, I would argue (following Robbins 2004) that these phrases are misleading and lead to simplistic linear and hierarchical thinking. Borrowing from anthropology, a better way to envision the relationship between various actors and events is to explore social and institutional networks, the various connections between people and institutions, how these factors are linked to regional, national, and even international events, and how an individual's natural resource-based practices at the local level are influenced by all these variables (Zimmerer and Bassett 2003, p. 207).

The real value of multiscalar, multimethod projects like the one presented here lies in the real-world solutions that they can produce. But much like inductive reasoning, the exact nature of these real-world solutions may not be immediately apparent at the beginning of the research process. As I concluded the book based on this research (Doolittle 2005), I thought that the most powerful and potentially useful findings were the insights my research provided into the cultural aspects of resource use and protection. The case of the rafflesia conservation and the local property relations around kepuna'an hutan [property of the forest] is a good example of the importance of social relations around property-at times, community reciprocity has a greater social importance than personal profits. Thus, a conservation program that reinforces the local norms of reciprocity is more likely to succeed than one based on private profit. I believed that if we could encourage political leaders to consider the value of local property and social relations for conservation, there would be possibilities to develop community-based conservation initiatives that would support both conservation and sustainable smallholder agriculture. In my research I saw many opportunities for innovative solutions based on a cultural understanding of natural resources and property relations that would benefit many sectors of Malaysian society. This model would facilitate community economic growth and would reduce conflicts between communities living along the boundaries of Kinabalu Park.

However, as the past decade has shown, the Sabah government will never make concessions to villagers that might interfere with the ability of the political leaders to control all valuable natural resources. The innovative solutions for conservation and rural development that I imagined as possible clearly are not in the immediate future of Sabah's people. In Malaysia's semidemocracy, where voter fraud and gerrymandering are the norm (Case 2001), political leaders do not suffer electoral loss as a result of long-term discontent from their electorate. And as long as the political and economic elite can continue to use state power to increase their own wealth and power, questions of conservation and rural livelihoods will be swept aside.

Knowing the highly volatile nature of native land rights in Sabah, one outcome of this research that I never envisioned was that it could be valuable for native peoples in their struggles against the ruling elite over the failure of the state to recognize their land rights. Yet in 2007 my research on the colonial treatment of native land rights became key evidence used in Sabah's High Court for a case of wrongful termination of native customary rights.

During the first half of 2007 I was in conversation with a NGO in Sabah, called PACOS, a community-based, voluntary organization that aims to build capacity in rural communities in Sabah on issues such as land and natural resource management. In January 2007 PACOS members 
were working as special consultants to a lawyer defending a landmark case on native customary land right in Sabah's High Court. The Chief Justice had given them several months to build a case based on customary law. A member of PACOS asked if I could help advise them on native customary law in Sabah. I encouraged them to read my book, which deals extensively with the colonial laws surrounding native customary land rights. I also sent along copies of many of the colonial documents on native customary law in Sabah that I copied from the Public Records Office in Kew, England. In July 2007 I heard that they won the case. In the ruling by the Justice of the High Court, more than 20 pages from my book were quoted (http:// www.kkhighcourt.com/Master_Schedule/master2007a.htm; cases JR 25-05-05, JR24-240-02, and K22-72-00; accessed 24 July 2007).

It is extraordinary to see such a direct link between social science research and a positive outcome for natives land rights. I followed the trail of more than a century of data from colonial officers in North Borneo, to people living in rural villages in Sabah, and back to my desk and computer, where I worked to untangle all the threads that contribute to issues of land and natural resource governance. When the book left my hands I had no way of envisioning that the next stop for these data would be Sabah's High Court. More positivistic-oriented colleagues tend to doubt the value of the kinds of place-specific, detailed data that a holistic approach to research produces. Many times I have been asked: "What is the value of qualitative research if we cannot replicate the results, test for validity, and generalize from the conclusions?" Based on the recent success of the native land rights case that was made possible by the qualitative data I produced, I feel more confident in saying that we may not be able to specify the value of qualitative research project at its inception. But this should not stop us from seeking out more holistic understanding of the human-environment relationship. Instead we should embrace, not struggle against, the indeterminacy and uncertainty inherent in the process of inductive reasoning. And by doing so we can be continually surprised by what the social world will reveal to us.

\footnotetext{
Acknowledgments The research on which this article is based was made possible by the financial support of Fulbright-Hays, Doctoral Dissertation Research Abroad Award, National Science Foundation, Law and Social Science Program, Dissertation Improvement Award (\#SBR 9511470), and the Social Science Research Council/American Council of Learned Societies, Southeast Asia Program, International Doctoral Dissertation Award. I want to thank the students in my methods course over the past 3 years, who have listened to my lectures on this topic and forced me to refine my ideas and articulate them more clearly. Additionally, I thank two anonymous reviewers, and Christian Kull and Arun Agrawal, whose comments helped me refine my presentation. As always, thanks go to the people of Sabah who opened their homes and lives to me.
}

\section{References}

Agrawal A (2005) Environmentality: technologies of government and the making of subjects. Duke University Press, Durham, NC

Agrawal A, Gibson C (eds) (2001) Communities and the environment: ethnicity, gender, and the state in community-based conservation. Rutgers University Press, New Brunswick, NJ

Agrawal A, Sivaramakrishnan K (2000) Agrarian environments: resources, representations, and rule in India. Duke University Press, Durham, NC

Alvesson M, Skoldberg K (2004) Reflexive methodology: new vistas for qualitative research. Sage, Thousand Oaks, CA

Babbie E (2004) The practice of social research. Thomson Learning, Belmont, CA

Barrett C., Brandon, C. Gibson, H. Gjertsen (2001) Conserving tropical biodiversity amid weak institutions. BioScience 51(6): 497-502

Bernard HR (2006) Research methods in anthropology: qualitative and quantitative approaches. AltaMira Press, Lanham, MD

Berry S (1993) No condition is permanent: the social dynamics of agrarian change in sub-Saharan Africa. University of Wisconsin Press, Madison

Blaikie P, Brookfield H (1987) Land degradation and society. Methuen, London

Booth WC, Colomb G, Williams J (2003) The craft of research. University of Chicago Press, Chicago

Brechin S, Wilshusen P, Fortwangler C, West P (eds) (2003) Contested nature: promoting international biodiversity with social justice in the twenty-first century. State University of New York Press, Albany

Brockington D (2002) Fortress conservation: the preservation of the Mkomazi Game Reserve, Tanzania. Indiana University Press, Bloomington

Bryant R, Bailey S (1997) Third world political ecology. Routledge, London

Bryant R (1997) The political ecology of forestry in Burma, 18241994. University of Hawaii Press, Honolulu

Case W (2001) Malaysia's resilient pseudo-democracy. Journal of Democracy 12(1):43-57

Chandran SMD (1998) Shifting cultivation, sacred groves and conflict in colonial forest policy in western Ghats. In: Grove R, Damodaran V, Sangwan S (Eds) Nature and the Orient: the environmental history of South and Southeast Asia. Oxford University Press, Delhi, pp 674-707

Comaroff J (1989) Images of empire, contests of conscience: models of colonial domination in South Africa. American Ethnologist 16:661-685

Conklin H (1957) Hanunoo agriculture: a report on an integral system of shifting cultivation in the Philippines. FAO Forestry Development Paper No. 12. FAO, Rome

Creswell J (2003) Research design: qualitative, quantitative, and mixed methods approaches. Sage, Thousand Oaks, CA

Demerath P (2006) The science of context: Modes of response for qualitative researchers in education. International Journal of Qualitative Studies in Education 19(1):97-113

Demsetz H (1967) Toward a theory of property rights. American Economic Review 57(2):347-359

Denzin N, Lincoln Y (eds) (1998) Strategies of qualitative inquiry. Sage, Thousand Oaks, CA

Doolittle A (2005) Property and politics in Sabah, Malaysia (North Borneo): a century of native struggles over land rights, 18811996. Nature and Culture Series. University of Washington Press, Seattle

Dove MR (1983) Theories of swidden agriculture, and the political economy of ignorance. Agroforestry Systems 1:85-99 
Dove MR (1998) Living rubber, dead land, and persisting systems in borneo: indigenous representations of sustainability. Bijdragen 154(1): $1-35$

Dove MR, Sajise P, Doolittle A (eds) (2005) Biodiversity and society in Southeast Asia: case studies of the interface between nature and culture. Southeast Asia Monograph Series. Yale University, New Haven, CT

Dunlop, W. n.d. Personal diary of W. R. Dunlop, 1897. Sabah Archives, File SP/1

Evans I (1922) Among primitive people in Borneo. Lippincott, Philadelphia

Fine G (2004) The when of ethnographic theory. American Sociological Association Theory Section Newsletter 27(1):4-5, 11

Forsyth T (2003) Critical political ecology: the politics of environmental science. Routledege, London

Fortmann L (1996) Gendered knowledge, rights and space in two Zimbabwe villages: reflections on methods and findings. In: Rocheleau D, Thomas-Slayter B, Wangari E (eds) Feminist political ecology: global issues and local experiences. Routlege Press, New York, London, pp. 211-233

Fox J, Truong DM, Rambo T, Tuyen NP, Cuc LT, Leisz S (2000) Shifting cultivation: a new paradigm for managing tropical forests. BioScience 50(6):521-528

Frank AG (1967) Capitalism and underdevelopment in Latin America. Monthly Review Press, New York

Glaser B, Strauss A (1967) The discovery of grounded theory: strategies for qualitative research. Aldine, Hawthorne, New York

Government of North Borneo (1914) Circular No. 95. August 14, 1914. North Borneo Chartered Company Archives No. 284. State Archives, Kota Kinabalu, Sabah

Government of North Borneo (1937) The ordinances and rules of the state of North Borneo, 1881-1936. Government Printing Office, Sandakan

Guha R (1963) A rule of property for Bengal. Mouton and Co., Paris

Guha R (1989) The unquiet woods: ecological change and peasant resistance in Himalaya. University of California Press, Berkeley

Guha R (1997) The authoritarian biologist and the arrogance of antihumanism: wildlife conservation in the third world. Ecologist 27(1):14-20

Guha R (1998) Radical American environmentalism and wilderness preservation. Environmental Ethics 11(1):71-83

Hesse-Biber SN,Leavy P (2005) The practice of qualitative research. Sage, Thousand Oaks, CA

Kinzig A (2001) Bridging disciplinary divides to address environmental and intellectual challenges. Ecosystems 4:709-715

Leach M, Fairhead J (2000) Fashioned forest pasts, occluded histories: international environmental analysis in West African locales. Development and Change 31:35-59

Leach M, Robins Mearns M, Scoones I (1999) Environmental entitlement: dynamics and institutions in community-based natural resources management. World Development 27(2):225247

Lincoln Y, Denzin N (1994) The handbook of qualitative research. Sage, Thousand Oaks, CA

Locke, J. 1690 [1963]. The second treatise of government. In Two treaties of government. P. Laslett, ed. Cambridge University Press, Cambridge

MacPherson CB (eds) (1978) Property: mainstream and critical positions. University of Toronto Press, Toronto

Merry SE (1988) Legal pluralism. Law and Society Review 22(5):867-896

Merry SE (1991) Law and colonialism. Law and Society Review 25(4):890-922

Migdal J, Kohli A, Shue V (eds) (1994) State power and social forces: domination and transformation in the Third World. Cambridge University Press, Cambridge
Moore SF (1986) Social facts and fabrication: customary law on Kilimanjaro, 1880-1980. Cambridge University Press, Cambridge

Murphree MW (2005) Congruent objectives, competing interests, and strategic compromise: concept and process in the evolution of Zimbabwe's CAMPFIRE, 1984-1996. In: Brosius P, Tsing A, Zerner $\mathrm{C}$ (eds) Communities and conservation: histories and politics of community-based natural resource management. AltaMira Press, Lantham, MD, pp 105-146

Nais, J (1996) Kinablau Park and the surrounding indigenous communities. Working Paper No. 17. South-South Cooperation Programme on Environmentally Sound Socio-Economic Development in the Humid Tropics. United National Educational and Scientific Organization

Nash R (2001) Wilderness and the American mind, 4th edn. Yale University Press, New Haven, CT

Neumann R (1998) Imposing wilderness: struggles over livelihood and nature preservation in Africa. University of California, Berkeley, Los Angeles

Neumann R (2005) Making political ecology. Hodder Arnold, New York, Oxford, UK

Ostrom E (1990) Governing the commons: the evolution of institutions for collective action. Cambridge University Press, New York

Paulson S, Gezon L (eds) (2005) Political ecology across spaces, scales, and social groups. Rutgers University Press, New Brunswick, NJ

Pearson AC (1914) Memorandum on forestry in the Philippines. Colonial Office 874/711. Public Records Office, Kew, UK

Peet R, Watts M (1996) Liberation ecology: development, sustainability, and environment in the age of market triumphalism. In: Peet R, Watts M (eds) Liberation ecologies: environment, development and social movements. Routledge, New York, pp 1-45

Peluso N (1993) Coercing conservation: the politics of state resource control. Global Environmental Change 4(2):199-218

Peters P (1994) Dividing the commons: politics, policy, and culture in Botswana. University Press of Virginia, Charlottesville

Pouchepadaas J (1995) British attitudes towards shifting cultivation in colonial South India: case study of South Canara District 18001920. In: Arnold D, Guha R (eds) Nature, culture, imperialism: essays on the environmental history of South Asia. Oxford University Press, Delhi, pp 123-151

Ragin C (1989) The comparative method: moving beyond qualitative and quantitative strategies. University of California Press, Berkeley

Ragin C (1994) Constructing social research: the unity and diversity of method. Sage, Thousand Oaks, CA

Redford K, Robinson JG, Adams WM (2006) Parks as shibboleths. Conservation Biology 20:1-2

Robbins P (2004) Political ecology: a critical introduction. Blackwell, Oxford, UK

Rocheleau D (1995) Maps, numbers, text and contest: mixing methods in feminist political ecology. Professional Geographers 47(4):458-466

Rose C (1994) Property and persuasion: essays on the history, theory, and rhetoric of ownership. Westview Press, Boulder, CO

Russell D, Harshbarger C (2003) Ground work for community-based conservation: strategies for social research. AltaMira Press, Lanham, MD

Rutter O (1922) British North Borneo: an account of its history, resources and native tribes. Constable \& Company, London

Scott J (1976) The moral economy of the peasant: subsistence and rebellion in Southeast Asia. Yale University Press, New Haven, CT

Scott J (1985) Weapons of the weak: everyday forms of peasant resistance. Yale University Press, New Haven, CT

Sivaramakrishnan K, Agrawal A (eds) (2003) Regional modernities: the cultural politics of development in India. Oxford University Press, New York 
Stake R (1995) The art of case study research. Sage, Thousand Oaks, CA Stoler A (1985) Capitalism and confrontation in Sumatra's Plantation Belt: 1870-1979. Yale University Press, New Haven, CT

Stott PA, Sullivan S (eds) (2000) Political ecology: science, myth and power. Arnold, London

Terborgh J (1999) Requiem for nature. Island Press, Washington, DC

Thompson EP (1971) The moral economy of the English crowd during the eighteenth century. Past and Present 50:76-115

Treacher W (1890) British Borneo: sketches of Brunai, Sarawak, Labuan and North Borneo. Journal of the Straits Branch of the Royal Asiatic Society XXI:19-122

Tsing A (1993) In the realm of the Diamond Queen: marginality in an out-of-the-way place. Princeton University Press, Princeton, NJ

Vayda A (1983) Progressive contextualization: methods for research in human ecology. Human Ecology 11(3):265-281

Verschuren P (2001) Holism versus reductionism in modern social science research. Quality \& Quantity 35:389-405
Wallerstein I (1974) The rise and future demise of the world capitalist system: concepts for a comparative analysis. Comparative Studies in History and Society 16:387-415

Weiss R (1994) Learning from strangers: the art and method of qualitative interview studies. Free Press, New York

Wells M, Brandon K (1992) People and parks: linking protected area management with local communities. World Bank, Washington $\mathrm{DC}$

Yin R (2002) Case study research: design and methods. Sage Press, Thousand Oaks, CA

Zerner C (1994) Through a green lens: the construction of customary environmental law and community in Indonesia's Maluku Islands. Law and Society Review 28(5):1079-1121

Zimmerer K, Bassett T (eds) (2003) Political ecology: an integrative approach to geography and environment-development studies. Guilford Press, New York 